\title{
Hybrid War Threats and Essence of Perception Management: Challenges for Pakistan Ajmal Abbasi*
}

\begin{abstract}
The Combat in the twenty first century is not only influenced by unprecedented technological and technical innovations but also characterized with progressive evolution of the art of warfighting. As the human and material costs of wars are getting untenable, the reliance seems to have shifted on cost-effective and result oriented strategies for defeating the enemy. Consequently, the approaches termed as hybrid, $4^{\text {th }}$ generation, $5^{\text {th }}$ generation, non-conventional, asymmetric and cyber warfare have been gaining currency. Pakistan is also among those states which are confronted with the challenge of hybrid war from its adversaries, particularly India. The prevailing ethno-nationalistic concerns, religious radicalization, political instability and socioeconomic issues are increasing the vulnerability of state against hybrid threats. With hybrid threat emerging as a tangible challenge, the art of perception management assumes vital significance. Given the unprecedented technological advancement in the cyber domain, the national security interests of Pakistan are increasingly linked with the effective perception management strategies.
\end{abstract}

Keywords: Hybrid wars, cyber operations, propaganda, public support, information exploitation

\footnotetext{
* The author is Ph.D. in the discipline of International Relations from Islamic International University, Islamabad. He specializes in the areas of war studies, Afghanistan and Iran affairs, while his research interests include conflict management, geopolitics, and political geography. He can be contacted at: ajmalabbasi23@yahoo.com
}

@2020 by the Islamabad Policy Research Institute.

IPRI Journal $\square \mathrm{XX}(2): 1-24$

https://doi.org/10.31945/iprij.200201

IPRI JOURNAL $\bullet$ SUMMER 2020 
Ajmal Abbasi

\section{Hybrid Warfare - The Historical Preview}

$\mathrm{H}$ ybrid warfare has usually been introduced as a phenomenon of the contemporary world that has gained currency in the last two decades, especially after the demise of the erstwhile Soviet Union. The term 'Hybrid' may not have necessarily been used in the ancient military doctrines; however, the human history is manifested with 'regular' as well as 'irregular warfare,' separately or in combination. The debate on the attributes of hybrid wars underlines the involvement of diverse players that blurs the traditional features, which segregate various modes of armed combats and even between war and peace. ${ }^{1}$ Interestingly, both the state as well as non-state actors, have been enormously rewarded with the employment of hybrid warfare strategy against their opponents. With the commencement of $21^{\text {st }}$ century, the word 'hybrid' has been commonly used to describe the contemporary warfare, predominantly due to the increasing involvement of non-state actors, besides the rising potential of cyber warfare. ${ }^{2}$ Hence, warfare in the contemporary world morphs into ostensibly alien modes through the fusion of regular as well as irregular forces, which are unleashed in the same battlefields. ${ }^{3}$

The term hybrid warfare gained popularity when Hezbollah militia effectively used non-conventional means against Israel in the 2006 conflict, while earlier, the concept was mainly linked with the fighting strategies of non-state actors ${ }^{4}$. After the invasion and annexation of Crimea by Russia in March 2014, the terminology of hybrid warfare gained worldwide focus and the recognition that it was equally viable strategy for the states as well, besides the non-state actors. ${ }^{5}$ With the passage of time, the hybrid warfare is now largely accepted as the most cost-effective strategy of waging a war against an adversary without direct involvement, which can help to

1 James K. Wither, "Making Sense of Hybrid Warfare," Connections 15, no. 2 (2016): 73-87 (74), https://www.jstor.org/stable/10.2307/26326441.

2 Ibid, 75.

3 Williamson Murray and Peter R. Mansoor, eds., Hybrid Warfare: Fighting Complex Opponents from the Ancient World to the Present (Cambridge University Press, 2012), 1, https://doi.org/10.1017/CBO9781139199254.

4 Tad A. Schnaufer, "Redefining Hybrid Warfare: Russia's Non-Linear War against the West," Journal of Strategic Security 10, no. 1 (2017): 17-31 (18), https://www.jstor.org/stable/10.2307/26466892.

5 Wither, "Making Sense of Hybrid Warfare," 73. 
Hybrid War Threats and Essence Of Perception Management:..

indirectly provoke a civil war in the targeted state. ${ }^{6}$ Palmer is of the view that during the Ukraine conflict, Moscow has aspired securing "politically decisive outcomes with, if possible, no or only a limited and overt use of military force, while being prepared to act militarily.... aim at attaining a decisive political advantage short of war."

With host of socio-political issues being confronted by the nationstates, especially the global South, the vulnerability of these countries against hybrid challenges is also on the rise. Documented involvement of India in the covert operations inside Pakistan through proxies and terrorist networks was revealed in 2009, when Pakistani premier handed over a dossier of Indian sponsored terrorist activities to his counterpart, during their meeting at Sharm-el-Sheikh in Egypt. ${ }^{8}$ Pakistan's vulnerabilities against hybrid threats, especially the ethno-nationalistic sentiments and religious radicalization fueled by Islamabad's decision to support American war against terror, allowed New Delhi to exploit the situation. India's involvement in hybrid warfare against Pakistan was again confirmed in 2013, when Indian Army Chief General Vijay Kumar Singh admitted that after the 2008 Mumbai attacks, a Tactical Support Division (TSD) was established to carry out terrorist attacks in Pakistan, and arrange financial support of Baloch dissidents. ' India's 'Hybrid Warfare' strategy against Pakistan, especially in strategically vital province of Balochistan was exposed with the apprehension of RAW agent Commander Kulbhushan Jadhav, a serving Indian Navy officer, who was apprehended near the border town of Chaman on March 3, 2016 during an intelligence-based operation. ${ }^{10}$ The Indian hybrid war effort essentially entails supporting the

6 Bastian Giegerich, "Hybrid Warfare and the Changing Character of Conflict," Connections 15, no. 2 (Spring 2016), 65-72 (66); and Andrew Korybko, "Applicability of Hybrid Warfare to Pakistan: Challenges and Possible Responses," NDU Journal 31, no. 1 (2017), 217, https://ndu.edu.pk/issra/issra_pub/articles/ndu-journal/NDU-Journal2017/12-Applicability-of-Hybrid-Warfare-to-Pakistan.pdf.

7 Diego A. Ruiz Palmer, Back to the Future? Russia's Hybrid Warfare, Revolutions in Military Affairs, and Cold War Comparisons, (paper, Research Division-NATO Defense College, Rome, 2015), 2, https://www.files.ethz.ch/isn/194718/rp_120.pdf.

8 Sehar Kamran, "Hybrid Warfare - Emerging Challenges for Pakistan," Nation, April 29, 2018, https://nation.com.pk/29-Apr-2018/592255?show=preview.

9 Ibid.

${ }^{10}$ Ikram Sehgal, "Hybrid Warfare Challenges for Pakistan," Daily Times, October 18, 2018, https://dailytimes.com.pk/311488/hybrid-warfare-challenges-for-pakistan/. 


\section{Ajmal Abbasi}

anti-state activities of dissident groups, fueling sectarian violence, financing ethno-nationalistic movements, casting doubts about the role of federation among smaller units, promoting social unrest and generating controversies over the China Pakistan Economic Corridor (CPEC).

\section{Defining the Hybrid Warfare}

Hybrid warfare appears to be a conflict which essentially stays well below the threshold of an all-out combat but the belligerents seek to exploit all vulnerabilities of the opponent for inflicting maximum damage. Hybrid warfare can thus be defined as:

conflict involving a combination of conventional military forces and irregulars (guerrillas, insurgents, and terrorists), which could include both state and non-state actors, aimed at achieving a common political purpose. ${ }^{11}$

Another definition of the hybrid warfare has been offered by Hoffman who states:

threats that incorporate a full range of different modes of warfare including conventional capabilities, irregular tactics and formations, terrorist acts including indiscriminate violence and coercion, and criminal disorder, conducted by both sides and a variety of non-state actors. ${ }^{12}$

According to the Military Balance edition (2015) hybrid warfare is: -

the use of military and non-military tools in an integrated campaign, designed to achieve surprise, seize the initiative and gain psychological as well as physical advantages utilizing diplomatic means; sophisticated and rapid information, electronic and cyber operations; covert and occasionally overt military and intelligence action; and economic pressure." 13

While the history of warfare is not oblivious of the fusion of regular as well as non-conventional means for battlefield gains, however, its influence has increased manifold in the contemporary world. As regular

11 Murray and Mansoor, "Hybrid Warfare," 2.

12 Frank G. Hoffman, Hybrid Warfare and Challenges, JFQ, no. 52 (2009), 8, https://apps.dtic.mil/dtic/tr/fulltext/u2/a516871.pdf.

13 Wither, "Making Sense of Hybrid Warfare," 76. 
Hybrid War Threats and Essence Of Perception Management:..

wars are turning into less preferred option due to political, financial and human outlays, and irregular means transpiring as most cost effective, easy to execute as well as rewarding strategy, many new facets of hybrid warfare are evolving. In the post-Cold War arena, the Ukraine conflict manifested triumphant application of subversion, cyber, proxies, conventional military interventions and maneuverers to deter and coerce the adversaries, thus leading to the introduction of hybrid warfare term by the analysts. ${ }^{14}$ Consequently, the hybrid warfare is broadly accepted as a viable option at all levels of war, from the tactical, to the operational, to the strategic, and has been served well with globalization and technical advancement. ${ }^{15}$ Pakistan since inception has been confronted with ethno-nationalistic issues, unfavorable state to nation ratio, socio-economic deprivations, and religious-sectarian radicalization - the challenges which expose a country to hybrid threats.

\section{Predominant Features of Hybrid War Strategies}

The concept of hybrid warfare neither adds up nor replaces earlier notions of irregular strategies, mostly deliberated with terminologies such as asymmetrical, new generation, non-linear, unrestricted, fourth or fifth generation warfare. The eventual goal of these concepts and means of warfare seems to exert unbearable psychological pressure on the targeted country, effecting near collapse of it for achieving the desired objectives even without resorting to violent physical combat. Hybrid war strategies are also employed preferably, when the opponent is deemed far superior and capacity of the state to wage a conventional conflict against the adversary is untenable. In the hindsight, the hybrid warfare inclines towards employing all combat strategies, which may not be exactly conventional in nature, but waged even between legitimately instituted armed forces of the nation-states. ${ }^{16}$ However, in case of Pakistan, while the country has been facing militarily far superior adversary, India, along its eastern borders, the most effective employment of hybrid threats emanated from the West by non-state actors, who have been active with the Indian patronage.

\footnotetext{
${ }^{14}$ Samuel Charap, “The Ghost of Hybrid War,” Survival 57, no. 6 (2015): 51-58 (53), http://dx.doi.org/10.1080/00396338.2015.1116147.

${ }^{15}$ Murray and Mansoor, "Hybrid Warfare," 3.

${ }^{16}$ Wither, "Making Sense of Hybrid Warfare," 79.
} 


\section{Ajmal Abbasi}

One of the fundamental attributes of hybrid threats is the fusion of conflict patterns, which were earlier regarded as isolated activities, but may now appear in diverse guise and would continue evolving. ${ }^{17}$ Whereas all the conceivable techniques employed in synchronization against the adversary during the combat are essential ingredients of the hybrid warfare, the use of coercive information operations has been distinguished as the most vital component of such as strategy. ${ }^{18}$ An essential element of hybrid warfare is thus information resources, which can be effectively used against the intended targets to manipulate the domestic public opinion and gain an influence on the consciousness of citizens. ${ }^{19}$ During the debacle of 1971 , India relentlessly propagated fictitious tale of Pakistan's atrocities against the Bengali population to infuse hatred against the state, a strategy which proved highly successful.

The hybrid warfare can be employed to organize effective coups d'état with external support, based on technologies that manipulate a population's protest potential, civilian killings on various pretexts, rampant crime, as well as mass uncontrolled migration, to achieve political objectives..$^{20}$ The key takeaway of the hybrid strategy is that most of the events occur covertly and well below the threshold of an armed conflict, much less war. ${ }^{21}$ The perpetual violence in Balouchistan, religious terrorism in Khyber Pakhtunkhwa (KPK), and targeting of the financial hub Karachi, by the elements patronized by hostile agencies reflect a bloody campaign, which nonetheless is below the threshold of an open armed conflict. In some instances, though not relevant to Pakistan, the states facing hybrid attacks are also confronted with the military challenges in the guise of conflict resolution and are relegated to conditions of chaos, domestic political crisis, and economic meltdown. ${ }^{22}$ The Syrian conflict can be a case study, where

\footnotetext{
${ }^{17}$ Bastian Giegerich, "Hybrid Warfare and the Changing Character of Conflict," Connections 15, no. 2 (2016): 65-72 (68), https://www.jstor.org/stable/10.2307/ 26326440.

${ }^{18}$ Wither, "Making Sense of Hybrid Warfare," 76.

${ }^{19}$ Timothy Thomas, "The Evolution of Russian Military Thought: Integrating Hybrid, New-Generation, and New-Type Thinking," The Journal of Slavic Military Studies 29, no. 4 (2016): 554-575 (558), http://dx.doi.org/10.1080/13518046.2016.1232541.

20 Thomas, "The Evolution of Russian Military Thought," 558.

${ }^{21}$ Giegerich, "Hybrid Warfare and the Changing Character of Conflict," 67.

22 Thomas, "The Evolution of Russian Military Thought," 558.
} 
Hybrid War Threats and Essence Of Perception Management:..

the US sought removal of the regime at Damascus through patronizing the anti-state elements who unleashed all ingredients of hybrid strategy against the government.

In contrast to the earlier times, when states enjoyed maximum conceivable sway over the means of shaping the public opinion, the success of hybrid warfare has accorded near equal capability to the non-state actors as well. Essentially, the emergence of hybrid warfare has somewhat reduced the monopoly of states over combat by offering considerable potential to the non-state actors. However, the involvement of states is inevitable since the non-state actors waging hybrid war against the intended target are largely operating as the proxy of some external player; radicals in the guise of Terek-e-Taliban Pakistan (TTP), Baloch armed dissident groups and terrorists active in Karachi have connections with India. Hence, the successful manifestation of hybrid war strategies has been accepted as a reality and the states aiming at hurting the interests of the adversary without an open war, may be more receptive to the possibility of resorting to unconventional means for desirable gains.

\section{The Stimuli for Hybrid Warfare}

The culmination of Cold War marked the end of ideological conflict between the capitalist and communist blocs, leading to the assumption that the unchallenged global domination of neo-liberal order would reduce chances of global confrontations in the future. There were expectations that quest for dominating the globe through a worldwide ideological contest would be substituted with economic calculations, resolving technical problems, addressing environmental concerns, and satisfaction of sophisticated consumer demands. ${ }^{23}$ Contrarily, warfare in the modern era continues to be symbolized by a violent ideological struggle while resorting to hybrid techniques, although mainly involving the non-state actors and the security threats emanating from a violent reaction generated as a side product of globalization. ${ }^{24}$

The countries like Pakistan with weak, corrupt and non-yielding governance structures result in public resentment thus making the state vulnerable to the potential hybrid war threats from the adversaries.

${ }^{23}$ Francis Fukuyama, “The End of History?” The National Interest, no. 16 (1989): 3-18 (18), https://www.jstor.org/stable/24027184.

${ }^{24}$ Michael Miller, Hybrid Warfare: Preparing for Future Conflict, report (Air War College, Air University, 2015) 12, https://apps.dtic.mil/dtic/tr/fulltext/u2/a618902.pdf. 


\section{Ajmal Abbasi}

Notwithstanding the type of government system, whether some form of democracy, autocracy or theocracy, the domestic fault lines are always of serious concern. The more the rulers are unpopular, non-representative and inept, the greater are the prospects of the success of hybrid warfare against such countries. Hence, with the rising globalization and resultant access of masses to diverse sources of negative information, the traditional governing structures are continuing to transform or unravel in the world, which can be a serious challenge for Pakistan as well. ${ }^{25}$

The clashes ensuing on the basis of historic, religious as well as ideological divergences result in violent political upheavals, leading to broader societal breakdown, state weakness, and humanitarian crisis. ${ }^{26}$ The government structures replacing colonial ruling arrangements in countries emerging as sovereign states like Pakistan, have been confronted with inherent ethnic diversities and longstanding social discords. Pakistan faced unfavorable nation to state ratio since its inception with ethno-nationalistic concerns getting deeply embedded in the society from the very beginning. Regrettably, the state apparatus did little to alleviate the concerns of the disillusioned ethnicities, which infused sense of deprivation and fueled annoyance with the federation.

The emergence of former colonies as sovereign nations without much consideration to the ethno-cultural composition of the newly born states, subjected them to the challenges of multi-culturalism. Pakistan is suffering from the multi-culturalism in different ways; the country was disintegrated in 1971 with Bengali population feeling deprived, while influx of refugees from Afghanistan, Bangladesh and even Myanmar has been spoiling the national cohesion. The influence of multi-culturalism is not regarded to be a security threat for countries like Pakistan alone but categorized as an equal challenge to the prosperous regions as well. The global north is also concerned with the invasion by immigration from global south, which is regarded as dangerous as invasion by a state force, calling it a poisonous multiculturalism. ${ }^{27}$

The under-developed former colonies in the global south including Pakistan, are faced with numerous existential threats, prominent being the

\footnotetext{
${ }^{25}$ Ibid., 11.

${ }^{26}$ David Kilcullen, Accidental Guerilla-Fighting Small Wars amongst a Big One, (London: Hurst \& Co, 2009), 35.

${ }^{27}$ Kirstie Ball and Laureen Snider, eds., The Surveillance-Industrial Complex: A Political Economy of Surveillance (Routledge, 2013), 16.
} 
Hybrid War Threats and Essence Of Perception Management:..

political fragility, which has emerged as the root cause of other ills. With majority of the population deprived of political representation as well as freedom, masses tend to rely on violence against the non-yielding governments. The resultant political instability and economic fragility cause domestic upheaval with persistent decline of state's authority, making it a prime target for hybrid attacks. Pakistan is facing the challenge of acute political polarization, failing of democratic institutions, questions over the civil-military relations, provincial divide, rising sway of regional groups fueling ethno-nationalist sentiments and growing radicalization amid minority but well entrenched support base of religious parties. ${ }^{28}$

In addition to the cultural drivers of conflicts such as historical grievances, religion and ideology, the traditional state security interests have also incited the outbreak of hybrid wars. ${ }^{29}$ Pakistan's creation and quest for survival in the face of a dominant adversary led to a strong religious orientation of the state, where ideological motivation served as the overriding driver for pursuing national security interests. In few instances, the religious affiliations of the individuals or the groups, associated them with a particular sect of Islam more than with Pakistan, making them vulnerable to manipulation either from foreign players or non-state actors such as radical clergy.$^{30}$ Hence, the security interests of the states have, at times led to such policies at national level, as is the case with Islamabad's strategy during Soviet invasion of Afghanistan, which at later stages, enhanced the vulnerabilities against the hybrid war threats.

The involvement of states with financial aid as well as supply of modern weapons and well-trained forces to the non-state actors, has made hybrid warfare an increasingly complex but certainly a viable option. ${ }^{31}$ Indian involvement in the terrorist activities on Pakistani soil is now welldocumented with the so-called "Doval Doctrine," linked with the former Research and Analysis Wing (RAW) chief, Ajit Doval, the National Security Advisor of Prime Minister Narendra Modi since 2014. ${ }^{32}$ New Delhi's policy of targeting Islamabd through hybrid war strategy transpires

\footnotetext{
${ }^{28}$ Ali Shah, "Understanding the Domestic Drivers of Pakistan's Hybrid War," Daily Times, June 15, 2019, https://dailytimes.com.pk/253587/understanding-the-domesticdrivers-of-pakistans-hybrid-war/.

${ }^{29}$ Miller, "Hybrid Warfare," 12.

${ }^{30}$ Korybko, "Applicability of Hybrid Warfare to Pakistan," 218.

${ }^{31}$ Miller, Hybrid Warfare, 13.

32 Kamran, "Hybrid Warfare."
}

IPRI JOURNAL $\bullet$ SUMMER 2020 


\section{Ajmal Abbasi}

with a Hindi phrase 'kante se kantanikalna;' used by Indian Defense Minister Manohar Parrikar, which reveals country's proclivity of using terrorists to catch or kill terrorists meaning that: "We should do it. Why does my soldier have to do it?" 33

In sum, the stimuli for hybrid warfare can be found in abundance among the countries of the global South, making these states highly vulnerable to potential threats. In addition to these frailties, the modern, highly sophisticated and easily accessible information technology in the contemporary world serves as the most potent life line for the hybrid warfare techniques. Reach and efficiency of social media in conveying the desired narrative to large audiences to support a political cause and for battlefield command and control, is unprecedented. ${ }^{34}$ Pakistan's security challenges against the hybrid war threats are enhanced manifold as the forces inimical to the country are well-versed in the employment of information war strategies with immense potential to exploit the existing vulnerabilities. While Pakistan is, at present, inadequately prepared for hybrid threats, however, increasingly sophisticated use of cyber warfare to disrupt or destroy state's industrial, financial and military networks, would be the hallmark of future conflicts. ${ }^{35}$

\section{Hybrid War Threats: A Conceptual Re-evaluation}

The growing receptivity of hybrid warfare cannot be regarded as the demise of customary or standard combat strategies, but it does complicate the defense planning process in the contemporary world. With numerous factors influencing conventional warfighting, the situation gets increasingly blurred, making the task of policy makers even more stringent. Historically though, there are certain examples which stimulate strategic responses against such challenges, however, dealing with networks that can fight in so many different ways-sparking myriads, hybrid forms of conflict, would definitely necessitate some innovative thinking. ${ }^{36}$ Besides many other inevitable measures, the states like Pakistan which are seriously threatened

\footnotetext{
${ }^{33}$ Sehgal, "Hybrid Warfare Challenges for Pakistan."

${ }^{34}$ Miller, Hybrid Warfare, 13.

35 Thomas Rid, Cyber War Will Not Take Place (USA: Oxford University Press, 2013), 14.

${ }^{36}$ John Arquilla, "The End of War as We Knew It? Insurgency, Counterinsurgency and Lessons from the Forgotten History of Early Terror Networks," Third World Quarterly 28, no. 2 (2007): 369-386 (369), https://doi.org/10.1080/01436590601153861.
} 
Hybrid War Threats and Essence Of Perception Management:..

with hybrid wars, would need perception management of the masses to avoid excruciating losses.

The hybrid challenges are largely unconventional in nature, hard to predict in advance or at the embryonic stage and may surface at a point when managing such threats becomes extremely complicated. While hybrid threats, being multifaceted, cannot be singlehandedly contested by any state institution, the armed forces would still be playing the most prominent role in defense strategy. Consequently, it would be imperative to place a premium on the cognitive skills needed to recognize or quickly adapt to the unknown, besides strong conventional military foundation. ${ }^{37}$

Armed forces of almost entire world including Pakistan are generally trained for dealing with the conventional military threats despite rising hybrid warfare challenges as well as involvement of the security organizations in post-9/11 war against terrorism. The counter insurgency operations by Pakistan Army in the former Federally Administrated Tribal Areas (FATA), now merged with KP, necessitated some doctrinal rethinking in traditional warfare with growing focus on asymmetrical fighting. It is, however, largely accepted that the successful response against hybrid wars would entail prompt decision-making at tactical level by small unit leaders, appropriate equipment and organizational reorientation. ${ }^{38}$ As hybrid war threats to Pakistan are multi-dimensional, the law enforcement agencies would need developing functional adaptability towards evolving challenges for an effective response.

The hybrid war challenges have the potential to evolve, mutate on the dictates of prevalent environments and predominantly rely on existent social, economic, political, ethnic and sectarian vulnerabilities of Pakistan for maximum gains. In order to respond effectively against potential hybrid threats, the states institutional mechanisms would require evolving for decentralization, flexibility and freedom of action at tactical level. During the hybrid warfare environments, it is vital to curtail the potential of adversary in exploiting the modern information technology, social media and cyber space - the most potent instruments for perception management. The hybrid threats emanating from the present-day mutating adversary as well as fusion of conflict modes, warrant prompt adaptability from all the

\footnotetext{
${ }^{37}$ Katharine K. Shobe and Wallace H. Wulfeck, "Decision Superiority: Putting the Emphasis Back on the Warfighter," (paper, Space and Naval Warfare Systems Center San Diego CA, 2009), 8, https://core.ac.uk/download/pdf/36729942.pdf.

${ }^{38}$ Hoffman, "Hybrid Warfare and Challenges," 38.
} 


\section{Ajmal Abbasi}

state institutions of Pakistan. Without adaption, even most advanced nations believe that they are destined to maintain and upgrade high-end, industrial age square pegs and be condemned for trying to force them into contemporary and increasingly complex round holes. ${ }^{39}$

With hybrid war challenge emerging as a tangible menace, there is a wider approval universally on the need for fresh deliberations over strategic re-orientation. It has been largely accepted that the "conflicts are increasingly characterized by a hybrid blend of traditional and irregular tactics, decentralized planning and execution, and non-state actors, using both simple and sophisticated technologies in innovative ways." ${ }^{40}$ Whereas hybrid threats may either transpire in the form of some state sponsored actions against the adversary, or a challenge initiated by the non-state actors, response in any case would have to be combined, multi-dimensional and all-encompassing. Pakistan is one of those states which faced hybrid war initiated through the employment of non-state actors as well as the one where Indian state involvement has been apparent.

Hezbollah's asymmetric strategy against the far superior Israeli Army in 2006 and later the 9/11 terrorist attacks on American mainland introduced the phenomenon of non-state actors, leading to the fresh strategic debate on warfare. Consequently, an inferior power may seek to employ all the dimensions of warfare to counter superior military capabilities asymmetrically, inflicting untenable costs in the process, for undermining domestic public support of the opponent. ${ }^{41}$ As the prospects of a state to state, all-out conventional war are diminishing, the belligerents are most likely to prefer option of hybrid means to hurt the interests of the opponents. In the context of South Asian dynamics, with Pakistan and India both emerging as the nuclear powers, the prospects of an all-out war between the two adversaries are declining, thus increasing the reliance on irregular conflicts. Presumably, the impending conflicts in the entire world including South Asia would be characterized with numerous indistinct variations in the conventional methodologies of war through the fusion of all available resources including the asymmetrical means.

\footnotetext{
${ }^{39}$ Frank G. Hoffman, "Conflict in the 21st Century: The Rise of Hybrid Wars" (paper, Potomac Institute for Policy Studies, 2007), 56, https://potomacinstitute.org/images/stories/publications/potomac_hybridwar_0108.pdf.

${ }^{40}$ Ibid., 39.

${ }^{41}$ Mackubin Thomas Owens, "Reflections on Future War," Naval War College Review 61, no. 3 (2008): 61-76 (73), https://www.jstor.org/stable/26396944.
} 
Hybrid War Threats and Essence Of Perception Management:..

\section{Perception Management}

\section{Understanding Perception Management}

Perception management is regarded as the fundamental ingredient of hybrid war strategies and considered a viable threat not only for underdeveloped countries like Pakistan but even by most advanced nations. Consequently, the FBI has listed perception management by external players as one of the eight 'key issue threats' to national security of the US since years, bracketing it with terrorism, attacks on critical infrastructure, and weapons proliferation among others. ${ }^{42}$ On the other hand, for Russian strategists, the perception management is a form of a 'reflexive control' - the vital component of maskirovka concept was conceived by Vladimir Lefebvre while exploring techniques of influencing opponent's decision-making processes. ${ }^{43}$ The maskirovka theory contemplates feeding purposefully conceived and twisted data, which prompts the adversary to willingly adopt policies that are in line with the strategy of the originator of the information. The essence of perception management continues to be a vital ingredient of warfare since the ancient times, whether deliberately or instinctively. Perception management thus assumes enormous significance for both, the instigator of the hybrid war as well as the one being targeted or the victim of this strategy.

According to the conventional wisdom, the aim of war is always a victory against the enemy even if this intended goal is without physical encounter in the battlefield. With large scale warfighting becoming increasingly redundant in the contemporary world, including nuclear armed South Asia due to potentially unattainable ramifications, art of combat is also in the process of rapid transformation for achieving desirable objectives. Hence, the war of perceptions has indeed become a decisive factor in the potential outcome of the conflicts and the side managing this facet of warfare is most likely to prevail against even the comparatively powerful adversary. Perception management can be thus termed as a process which is aimed at influencing masses by diluting adversary's will while consolidating one's own, and persuading bystanders of the

\footnotetext{
${ }^{42}$ Matteo G. Martemucci, Regaining the High Ground: The Challenges of Perception Management in National Strategy and Military Operations, report (Joint Forces Staff College Joint Advanced Warfighting School), 2007, 6, https://apps.dtic.mil/dtic/tr/fulltext/u2/a468873.pdf.

${ }^{43}$ Wither, "Making Sense of Hybrid Warfare," 82.
} 


\section{Ajmal Abbasi}

righteousness of one's cause. ${ }^{44}$ The techniques employed for gaining desirables through perception management can include blackmail, camouflage, deception and disinformation, all envisioned to influence an enemy's decision-making cycle for a favorable outcome. ${ }^{45}$

In the present-day world, the military ventures are characterized with the essence of legitimacy, which implies that certain legal, moral, and ethical parameters are observed during the combat. ${ }^{46}$ Consequently, where ease of access to the information makes the credibility as well as legitimacy of the actions vital for gaining the popular support, need for perception management also becomes imperative. The war of perception has thus transformed from earlier orthodox concepts of 'traditional propaganda' and 'psychological warfare' to all-encompassing and all-inclusive domains of 'information warfare', 'information operations' and 'psychological operations. ${ }^{, 47}$ Perception management seeks domestic public support for the intended policies while externally, the perceptions of targets are shaped in a way to get them aligned with the desired outcome. ${ }^{48}$ Resultantly, the control over perceptions not only influences the policy formulation process of the states but also serves as one of the most potent invisible weapons against the intended targets.

Furthermore, perception management aims at constructing and sustaining the popular support of the domestic as well as targeted audience for gaining legitimacy of the actions in hand. If the war can be projected as the just war (jus ad bellum) through perception management, it is expected to gain legitimacy in the public opinion. The terrorist attack on Army Public School Peshawar on December 16, 2014, resulting in the killing of 141 people, including 132 children, had a major role in shaping the national

\footnotetext{
${ }^{44}$ John Arquilla and Douglas A. Borer, eds., Information Strategy and Warfare: A Guide to Theory and Practice (Routledge, 2007), 5.

${ }^{45}$ Wither, "Making Sense of Hybrid Warfare," 82.

${ }^{46}$ Pascale Combelles Siegel, "Perception Management: IO's Stepchild?” Low Intensity Conflict \& Law Enforcement 13, no. 2 (2005): 117-134 (119), http://dx.doi.org/10.1080/09662840500347314.

${ }^{47}$ Aki Huhtinen and Jari Rantapelkonen, "Perception Management in the Art of War. A Review Of Finnish War Propaganda and Present-Day Information Warfare," Journal of Information Warfare 2, no. 1 (2003): 50-58, https://www.jstor.org/stable/26486889.

${ }^{48}$ Siegel, "Perception Management," 119.
} 
Hybrid War Threats and Essence Of Perception Management:..

resolve against the horrendous activities of the militants in Pakistan. ${ }^{49}$ Thus, legitimacy of the war is reflected from its mandate, utmost regards of the combat norms as well as respect for the humanitarian principles, which can influence the perceptions of the masses. ${ }^{50}$ As perception management is essentially seeking some degree of control over intellect and thoughts on the targeted communities, it therefore becomes a contest of narratives. At times, the manipulation of facts based on a particular strategy means the distortion of information to an extent that targeted communities, who have a true perception of an existing reality, are led to a false one. ${ }^{51}$

\section{Evolution of Perception Management Strategy}

Notwithstanding the diverse forms, means or intentions, warfare is recognized as the contest amongst rival entities with the sole objective of defeating the opponent. The belligerents persistently evolve new and innovative plans to offset strategic deficiencies against the adversaries and seek to keep the human as well as material cost at the minimum. In this process, as stated by Clausewitz, the fog of uncertainty has been a fundamental property of military action, therefore, influence campaigns add the fog of military action and keep the adversary oblivious of real intentions. ${ }^{52}$ Consequently, perception management cannot be branded as a new technique since historically, well designed psychological campaigns against the enemies helped in demoralizing them during or even prior to the war. In the contemporary world where hybrid warfare has added new complexities to the threat spectrum, defense against multidimensional challenges to the national security, especially from propaganda wars, is getting increasingly demanding. Essentially, the propaganda, psychological campaigns or the introduction of terminologies such as information warfare, are all aimed at influencing the perceptions of the targeted audiences.

While historically, the armed operations had been seeking to compel the adversaries into a preferred course of action with either actual use of force or mere intimidation if possible, the perception management was at

\footnotetext{
49 "Pakistan Taliban: Peshawar School Attack Leaves 141 Dead," BBC News, December 16, 2014, https://www.bbc.com/news/world-asia-30491435.

${ }^{50}$ Ibid.

${ }^{51}$ Martin C. Libicki, Conquest in Cyberspace: National Security and Information Warfare (Cambridge University Press, 2007), 29.

52 Arquilla and Borer, Information Strategy and Warfare, 72.
} 


\section{Ajmal Abbasi}

the heart of these military campaigns, though in varying forms. ${ }^{53}$ The Perception warfare can therefore be termed as a concept that outlines the occurrences which give illusions of all as winners in their own way. ${ }^{54}$ Perception management can be categorized as a vital part of the broader combat strategy, primarily aimed at not only influencing the premier decision-making hierarchy of an adversary but the general public also ${ }^{55} \mathrm{In}$ multi-ethnic and multi-cultured states like Pakistan, the aggrieved communities, whether justified or otherwise, are generally predisposed towards intellectual manipulation and fell easy prey to hostile propaganda.

As deliberated thus far, the successful perception management drives in all conceivable modes, had been the recipe of prevailing over the adversary with minimum possible human as well as material losses and evolved in the process. In the prevailing environments, the emerging cyberspace has enormous impact on the customary notion of national borders, proffering state and non-state actors plenty of opportunities to manipulate the information. The ease of access to various sources of information, even among the states of global south including Pakistan, generating situational awareness becomes imperative for ensuring adequate response. Consequently, the internet and other social media applications enable manipulation of information and thus facilitate dissident political entities and international as well as domestic non-governmental organizations in influencing public perception of the targeted states. Whereas the structured and well-deliberated employment of deception means has historical antecedents, current state-of-the-art expedients offer perception manipulators a powerful set of new tools. ${ }^{56}$ Therefore, modern warfare can be regarded as the battle of trust, where not only the truth is sought, but instead efforts are also launched for controlling the truth and

\footnotetext{
${ }^{53}$ Siegel, "Perception Management," 119.

${ }^{54}$ Henrik Friman, "Perception Warfare: A Perspective for the Future,"1, accessed 01 March 2020, https://pdfs.semanticscholar.org/dd49/7313c8ffcc1028d914620fb0c53d55d8a2e9.pdf.

55 Peter Callamari and Derek Reveron, "China's Use of Perception Management," International Journal of Intelligence and Counter Intelligence 16, no. 1 (2003): 1-15 (2), http://dx.doi.org/10.1080/713830380.

${ }^{56}$ Roger C. Molander et al., Strategic Information Warfare: A New Face of War (Rand Corporation, 1996), 15.
} 
Hybrid War Threats and Essence Of Perception Management:..

projecting what is deemed essential for the successful execution of the plan. $^{57}$

\section{Defining Perception Management}

Generally, perception is the inbuilt capacity of the human beings to assess the world and the events taking place around them and formulate an opinion, however, empirically, there are various stimulations which influence individual's perspection of an existing reality. As is stated by Aeschylus, "truth is the first causality in the war" hence; fueling the misperceptions and distortions of information as part of the war strategy are common during the conflicts. ${ }^{58}$ Thus, the ability to have some degree of control over the stimulations effecting human opinion favorably and according to a desirable narrative can be termed as the perception management. In the contemporary world, continuous evolution of information technology has considerably enhanced the power of deception and image-manipulation activities, therefore, radically complicating defense against impending perception management efforts by the adversaries. ${ }^{59}$ Apparently, perception management is the informationprocessing capability and a center of gravity for every one; the side which gains some degree of control over opponent's information while preserving its own, is likely to prevail. ${ }^{60}$

The emergence of hybrid warfare strategy has convinced the belligerents to focus on the psychological gains against the adversary through perception management, which is planned systematically and deliberately. The term 'perception management' can be recognized as part of information warfare and often used in conjunction with 'media warfare,' highlighting that the contemporary mass media sources are employed for disseminating propaganda or supporting the deception operations. ${ }^{61}$ US DoD (2001) defines perception management as:

\footnotetext{
${ }^{57}$ Friman, "Perception Warfare," 5.

${ }^{58}$ Arquilla and Borer, Information Strategy and Warfare, 72.

${ }^{59}$ Molander et al., Strategic Information Warfare, xiv.

${ }^{60}$ Peter D. Feaver, "Blowback: Information Warfare and the Dynamics of Coercion," Security Studies 7, no. 4 (1998): 88-120 (88), http://dx.doi.org/10.1080/096364 19808429359.

${ }^{61}$ Scot Macdonald, Propaganda and Information Warfare in the Twenty-First Century: Altered images and deception operations (Routledge, 2006), 4.
} 
Ajmal Abbasi

Actions to convey and/or deny selected information and indicators to foreign audiences to influence their emotions, motives, and objective reasoning as well as to intelligence systems and leaders at all levels to influence official estimates, ultimately resulting in foreign behaviors and official actions favorable to the originator's objectives. In various ways, perception management combines truth projection, operations security, cover and deception, and psychological operations. ${ }^{62}$

Although, the perception warfare ostensibly differs from information warfare, however, both have certain commonalities; initiatives such as, command and control warfare, intelligence based warfare, electronic warfare, psychological warfare, hacker warfare, economic information warfare, cyber warfare, propaganda, deception warfare and misinformation are the practical manifestations of information warfare. ${ }^{63}$ As the strategy of information exploitation seeks to influence the public opinion of the target, it is essentially a form of propaganda. ${ }^{64}$ Thus, the "perception management may well be another pseudonym for propaganda," but, the modern usage of the strategy and its potential impact on the targeted audience is far more wide-ranging. ${ }^{65}$ Alternatively, the perception management differs from propaganda since it is the articulation of desired message in a form, which is comprehended by the targeted audience and intended to construct their opinions favorably. ${ }^{66}$

\section{Perception Management in the Hybrid Warfare}

The strategy of perception management can be widely differentiated from the conventional military deception, as it is methodical in comparison and aims at gradually persuading the target on implementing desirable policies. This effort may involve the manipulation of the adversary's perception by

${ }^{62}$ United States Department of Defense, The Dictionary of Military Terms (Skyhorse Publishing Inc., 2001), 332.

${ }^{63}$ Friman, "Perception Warfare," 2.

${ }^{64}$ Feaver, "Blowback," 92.

${ }^{65}$ Philip M. Taylor, "Perception management and the 'war' against terrorism," Journal of Information Warfare 1, no. 3 (2002): 16-29 (25), https://www.jstor.org/stable/26504100.

${ }^{66}$ Andrew Garfield, "The Offence of Strategic Influence: Making the Case for Perception Management Operations," Journal of Information Warfare 1, no. 3 (2002): 32, https://www.jstor.org/stable/26504101?seq=1. 
Hybrid War Threats and Essence Of Perception Management:..

seeking to influence its decision making, through either fabricating a situation or crafting an objective that would ultimately support the originator's intended plan. ${ }^{67}$ It has almost become a norm that realities about an occurrence or happening are engineered to project a specific agenda through the effective use of available text, audio, as well as video means. These techniques facilitate a wide variety of actors in the initiation and successful execution of sophisticated perception management that seeks to undermine domestic backing over a certain course of action. ${ }^{68}$ Indian media has, over the years, productively advanced state's antiPakistan agenda, particularly among the domestic audiences and virtually served as the vanguard of the government patronized perception management drive.

In the hybrid warfare, the perception management seeks to shape the public opinion in a way that the decision makers are essentially isolated from people, thereby, allowing adversary to subconsciously influence the mindset of the target and inflict psychological defeat. The successful perception management drive may compel an oblivious rival to unintentionally assume a deliberately constructed plot and take decisions which are in the interests of the adversaries. During the East Pakistan debacle, the Indian patronized elements effectively managed perceptions of the Bengali masses against Islamabad, leading to a situation where the country was eventually disintegrated. Essentially, information exploitation, or perception management, implies controlling or managing adversary's decision making by manipulating the information received by the target. ${ }^{69}$ According to the American Central Intelligence Agency (CIA):

Perception - the process of forming images of the world, can be thought of as involving two sub-processes. Sensory data is first acquired, then [it is] organized and analyzed to form a coherent, comprehensive picture. Thus, misperception of the world can arise either from incorrect data, or from malprocessing of correct data. ${ }^{70}$

Perception management strategy cannot, however, be a limited initiative with a sole activity of communicating intended messages to the

\footnotetext{
${ }^{67}$ Callamari and Reveron, "China's use of Perception Management," 2.

${ }^{68}$ Molander et al., Strategic Information Warfare, 23.

${ }^{69}$ Feaver, "Blowback," 92.

${ }^{70}$ Callamari and Reveron, "China's Use of Perception Management," 2.
} 


\section{Ajmal Abbasi}

targeted audience. It shall be regarded as a far more comprehensive endeavor, combining verbal and physical actions both, which may include the kinetic as well as non-kinetic means to shape the perception of the target. The employment of kinetic actions may emerge as one of the ingredients of the perception management strategy, nevertheless, generally the focus is limited to non-kinetic means that essentially form a part of contemporary information warfare. As part of a viable strategy, an existing social, economic, ethnic or religious wedge can be exploited against the adversary by targeting the dissident segments of the population who differ on key psychological dimensions with specific, divisive messages. ${ }^{71}$ Pakistan being a nuclear power may not be overly exposed to the kinetic threats, however, the country is confronting pressure from adversaries along the borders with persistent fire raids and cease fire violations. The kinetic actions against Pakistan are mostly in synchronization with non-kinetic events, which may include some kind of domestic upheaval, major terrorist activity, an international incident with some negative repercussions or internal political instability.

\section{Augmenting Perception Management Drive}

Perception management can be effectively influenced with the following initiatives: -

- The task of perception management can become easier when a feeling of discrimination due to a perceived discrepancy between one's actual fate and that to which one feels entitled exists and the effected choose to restore justice, including resorting to violence and aggression. ${ }^{72}$ This phenomenon is known as the Perceived Relative Deprivation (PRD) and plays a vital role in alienating an aggrieved community. In multi-ethnic federations like Pakistan, the discontent among any particular community over some issue can be easily exploited by the hostile agencies. Activities of Baluch dissident groups and the sudden rise of the Pashtun Tahafaz Movement (PTM), besides the synchronization of their demands with externally pursued agenda is a case in point.

- While education aims at projecting a neutral interpretation, propaganda consists of delicately promoted narratives for vested

${ }^{71}$ Arquilla and Borer, Information Strategy and Warfare, 68.

${ }^{72}$ Ibid," 70. 
Hybrid War Threats and Essence Of Perception Management:..

interests by exploiting prevailing realities, but the prejudice is well conceived in the process. The insurgency leading to the disintegration of East Pakistan had initially taken roots in the educational institutions where anti-state vibes were intense. In the present-day Pakistan, some of the privately owned educational institutions are doubted for promoting vested agendas against the state. Even in some cases, the syllabus books contain highly objectionable material, which is polluting the young minds and infusing feeling of revulsion vis-à-vis the religious, national, cultural and social values.

- Propaganda can be an influential means of perception management as it productively coalesces entertainment and education while coaxing the intended targets. The programs of entertainment attract the audience, while the educational aspect decreases the perception that the message is propaganda, even as it persuades ${ }^{73}$ Pakistani policy makers had to take notice of the disruptive influence of Indian cable networks on the social fabric of the country and its potential ramifications on the national interests.

- The ease of executing propaganda on the name of education makes it a viable perception management strategy as the difference between the two is just post hoc rationalization: if a persuasion attempt fails, it is called propaganda; if it succeeds, it is called education. ${ }^{74}$ Notwithstanding ban on the Indian cable channels in most parts of Pakistan, the influx of foreign movies/ entertainment programs on national media and exposure of the masses to negative propaganda has emerged as a serious challenge for the state. Many activities in the guise of education in few private institutions are promoting anti-state narratives.

- Perception of target can also be influenced through the pictorial display of military equipment, projections regarding military might and other related aspects exhibiting overwhelming material superiority. Hence, the use of photographs may help distort public opinion about a conflict besides staging a deception over a tactical situation through highlighting a specific narrative.

\footnotetext{
${ }^{73}$ Macdonald, Propaganda and Information Warfare in the Twenty-First Century, 32.

${ }^{74}$ Ibid.
} 
Ajmal Abbasi

The employment of modern gadgetry for perception management is on display in South Asia as well and Pakistan and India both use it more often than not, against each other.

- Perception management cannot yield desired output if it is at variance with the prevailing public opinion of the targeted community or lacks relevance at a particular point in time. A specific narrative can entice public attention if it diligently reinforces already existing perceptions of the intended target, thus evolving a tacit symbiotic connection and coalescing of interests between the two. PTM has been able to exploit Pashtun sentiments due to the sufferings of the community, especially in areas which have been devastated with the activities of the terrorist groups as well as the military operations against terrorism. Likewise, the anti-federation elements in Pakistan also exploit social injustices, economic frailties, political deprivations and religious/sectarian sentiments.

- While it is inevitable to undertake logical perception management by keeping faith on reality, construction of plausible as well as intended narrative would still warrant spin of the truth. Hence, the truth should continue to prevail and reported but for shaping the perceptions; interpretation of the reality according to the desired narrative becomes unavoidable. The negativity about Pakistan's role in the war against terror, allegations of human rights violations by the state institutions, missing persons issue, religious radicalization and concerns of three smaller federating units are often blown out of proportion by the hostile agencies. As a part of classic hybrid war strategy, not only the country is maligned internationally but the domestic audiences also get disillusioned from the state and its institutions.

- A methodically constructed distortion of facts or incorrect information mostly seems correct or valid and may very conveniently help in disseminating a contorted story. Moreover, scandalous, sensationalized and embellished narrative often entice public opinion and can have far more persuasive impact compared to factual information. It is also easier to quickly spread wrong and dramatized news as public is more receptive to propaganda and rumors. This strategy has been visible when some disgruntled elements exploited the extra-judicial killing of a Pashtun young man Naqibullah Mehsud by police at Karachi 
Hybrid War Threats and Essence Of Perception Management:..

on January 18,2018 , for raising anti-state agenda. ${ }^{75}$ While the incident was a reality and atrocity by police was also a proven fact, however, the narrative spread by few elements had served vested interest against the state and its institutions.

\section{Conclusion}

Evolution of the art of warfare to present stratum and growing receptivity of hybrid strategies, can be regarded a congenital process, where belligerents seek to counter adversary's military ascendancy with all perceivable means. The versatility of the hybrid warfare strategies, potential military rewards for even those facing comparatively superior adversary and the adaptability of such techniques in all ambiences makes it a feasible option. It has been accepted that the "hybrid warfare will be a defining feature of the future security environment." 76 While the hybrid warfare would continue to evolve in the future, however, it cannot be specifically categorized into either offensive or defensive strategy. Hybrid techniques being adaptable, are equally workable as a cost-effective offensive strategy, whereas its defensive employment against a dominant aggressor can also be rewarding. The hybrid warfare is summarized as under: -

In any case, the boundaries between conventional and unconventional, regular and irregular warfare are blurring. Even non-state groups are increasingly gaining access to the kinds of weapons - from missiles and land mines to chemicals and perhaps even atomic bombs - that were once the exclusive preserve of states. ${ }^{77}$

In the modern times, the hybrid wars or fighting against the invisible enemy have become more challenging, since the technological advances in the information operations offer many leverages to those aiming at perception management. The strategy of information exploitation for perception management, whether it is by a state or some non-state actors,

75 Asim Khan, "Naqeebullah Mehsud was Innocent, Was Killed in a Fake Encounter," Dawn, January 24, 2018. https://www.dawn.com/news/1384767.

${ }^{76}$ Michèle A. Flournoy and Shawn Brimley, "The Defense Inheritance: Challenges and Choices for the Next Pentagon Team," Washington Quarterly 31, no. 4 (2008): 59-76 (63), https://doi.org/10.1162/wash.2008.31.4.59.

${ }^{77}$ Max Boot, War Made New: Technology, Warfare, and the Course of History, 1500 to Today (Penguin, 2006), 297. 


\section{Ajmal Abbasi}

resembles the art of diplomacy, as both aim at influencing decision making of the targeted community. While the diplomatic maneuvering is an initiative launched externally, the information exploitation primarily relies on manipulating adversary's decision making domestically, though making sure that the entire process appears as natural and without revealing the true intentions. In the conflict of narratives, the persuasive, more convincing and logically built interpretations are likely to prevail in explaining different words and images projected through information wars. Therefore, the indepth understanding of any complex phenomenon warrants the capacity to look behind images and simple modes of speech and respond accordingly. ${ }^{78}$

With hybrid warfare emerging as one of the most viable security challenges for Pakistan, involving both state as well as non-state actors, the essence of perception management assumes far greater significance, especially due to prevailing domestic fault lines of the country. Nevertheless, the efforts towards the perception management may not always yield the desired results since a commanding as well as flexible strategy against both, the visible as well as invisible adversaries is hard to achieve, not only for a country like Pakistan but even for the most advanced states. Perception management initiatives may have dual impact since the attempt to manage sensitive perception can be at times counter-productive also. ${ }^{79}$ In essence, quantifying the impact of perception management appears unrealistic, given the abstract nature of its influence on targeted population. Another aspect which assumes significance during the perception management planning is the understanding that the perceptions are mostly contextual in nature. Consequently, perception management is a delicate art, which requires thorough planning and can only be successful when the barriers of culture, locally thriving perspections, religious inspirations and historically existent narratives are effectively addressed.

\footnotetext{
${ }^{78}$ Huhtinen and Rantapelkonen, "Perception Management in the Art of War," 253.

${ }^{79}$ Ibid., 252.
} 